\title{
Folyóiratunk olvasottságáról
}

\author{
About the journal popularity
}

doi: 10.24365/ef.v58i4.219

Nagy örömünkre az Egészségfejlesztés folyóirat olvasottsága töretlenül növekszik, ami jól mutatja az egészségfejlesztés iránti érdeklődést és a téma fontosságát.
A folyóirat napi átlagos látogatóinak száma már közel 180, az idei év harmadik számának megjelenésétől kezdve - októbertől - pedig a havi látogatószám meghaladja az 5000-et [1. ábra].

\section{1. ábra: A folyóirat honlapját havonta, illetve naponta átlagosan meglátogatók száma}

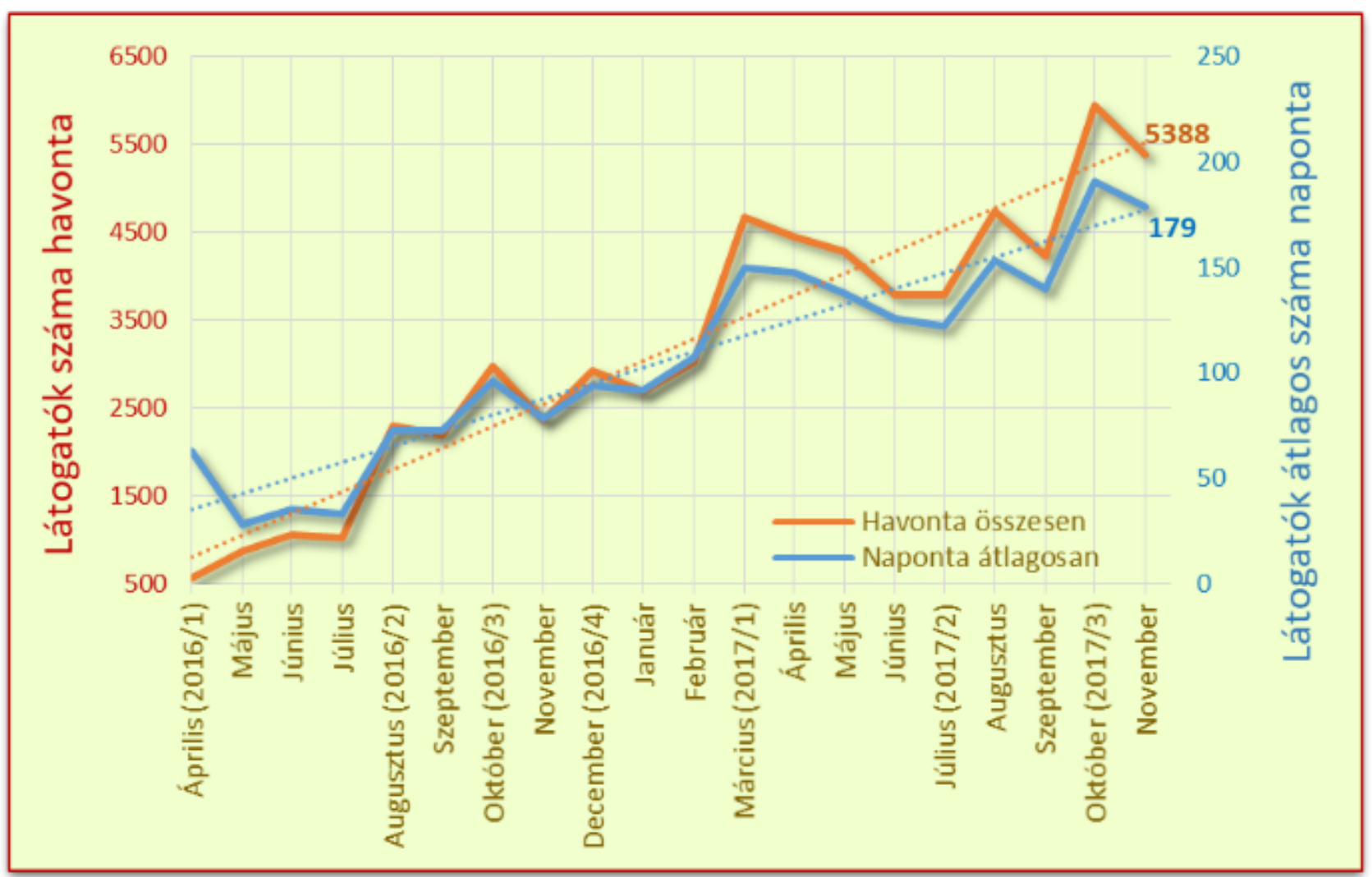

A korábbi számokhoz hasonlóan elkészítettük a legtöbbet olvasott 10 cikk három különböző szempont alapján összeállított rangsorát: (1) az összefoglaló és (2) a teljes cikkek olvasottságát, valamint (3) az egyes cikkek elérhetőségét, azaz a megjelenés óta eltelt idő hosszát is figyelembe véve.
A legtöbbször olvasott összefoglalók 10-es listáján nem történt változás az előző lapszám megjelenése óta. A teljes közlemények olvasottságát nézve magasan kiemelkedik a csecsemőkori allergiamegelözés korszerű irányelveiről szóló írás és az első 10 közé bekerült a tavalyi év 2 . számában megjelent, a 
vakcináció „tízparancsolata” felnőttek védőoltásaihoz című cikk is. A publikálása óta eltelt idő alatt a legtöbbet olvasott cikkek között továbbra is a csecsemőkori allergiamegelőzés korszerű irányelveit bemutató cikk az első, ez is mutatja a téma fontosságát. [1. táblázat] A legutóbbi lapszámból 6 közlemény is szerepel a 10-es rangsorban, így ezek sok olvasónk érdeklődését keltették fel, például a leggyakoribb nemi betegségekre vonatkozó ismeretek cikksorozat első része, az egészség ökoszociális elméletét bemutató írás és a „Hogyan fejlesszük egy ország egészségkultúráját? A RAND Corporation jelentésének ismertetése" címú közlemény.

1. táblázat: A közlemények elérhetőségét is figyelembe vevő olvasottsági rangsor

\begin{tabular}{|c|c|c|c|}
\hline $\begin{array}{l}\text { Olvasottság/ } \\
\text { eltelt idő }\end{array}$ & Közlemény címe & Szerző(k) & Lapszám \\
\hline 7,17 & $\begin{array}{l}\text { A csecsemőkori allergiamegelőzés korszerű irányelvei és } \\
\text { lehetőségei }\end{array}$ & Réthy A & 2017. 1. szám \\
\hline 2,24 & $\begin{array}{l}\text { Az egészségügyi ellátáshoz való hozzáférés területi egyen- } \\
\text { lőtlenségeinek vizsgálata az akut miokardiális infarktus } \\
\text { okozta halálozás adatainak felhasználásával }\end{array}$ & $\begin{array}{l}\text { Uzzoli A, Vitrai J, } \\
\text { Tóth G }\end{array}$ & 2017. 3. szám \\
\hline 1,87 & $\begin{array}{l}\text { A leggyakoribb nemi betegségekre vonatkozó ismeretek } \\
\text { középiskolai pedagógusok számára I. rész }\end{array}$ & $\begin{array}{l}\text { Burián K, } \\
\text { Spengler G }\end{array}$ & 2017. 3. szám \\
\hline 1,43 & $\begin{array}{l}\text { Hogyan fejlesszük egy ország egészségkultúráját? A RAND } \\
\text { Corporation jelentésének ismertetése }\end{array}$ & $\begin{array}{l}\text { Kaposvári Cs, } \\
\text { Vitrai J }\end{array}$ & 2017. 3. szám \\
\hline 1,16 & $\begin{array}{l}\text { Az ülő életmód és az elhízás fiatalok körében: áttekintő ta- } \\
\text { nulmány a kapcsolódó felmérésekről és oksági elemzések- } \\
\text { ről }\end{array}$ & Varga A & 2017. 3. szám \\
\hline 1,09 & $\begin{array}{l}\text { Az étkezési magatartás összefüggése az ételválasztási mo- } \\
\text { tivációkkal és pszichológiai jellemzőkkel középiskolások kö- } \\
\text { rében }\end{array}$ & Szabó K, Pikó B & 2017. 2. szám \\
\hline 1,07 & Az egészség ökoszociális elmélete & Csizmadia P & 2017. 3. szám \\
\hline 0,95 & Félúton vagy tévúton? & szerkesztőség & 2017. 2. szám \\
\hline 0,92 & $\begin{array}{l}\text { Komplex egészségfejlesztési beavatkozások lehetséges } \\
\text { prevenciós megközelítései }\end{array}$ & $\begin{array}{l}\text { Járomi É, } \\
\text { Kimmel Zs }\end{array}$ & 2017. 2. szám \\
\hline 0,88 & $\begin{array}{l}\text { Tisztelettel adóztak az anyák megmentőjének - 2017. évi } \\
\text { Semmelweis ünnepség Győr-Szigetben }\end{array}$ & Schmidt P & 2017. 3. szám \\
\hline
\end{tabular}

